\title{
TV/Series
}

$1 \mid 2012$

Les Séries télévisées américaines contemporaines :

entre la fiction, les faits, et le réel

\section{Alan Ball's California and Louisiana Series, Six Feet Under \& True Blood: a Troubled State of the Nation}

Anne-Marie Paquet-Deyris

\section{(2) OpenEdition}

\section{Journals}

Electronic version

URL: http://journals.openedition.org/tvseries/1195

DOI: 10.4000/tvseries.1195

ISSN: 2266-0909

Publisher

GRIC - Groupe de recherche Identités et Cultures

Electronic reference

Anne-Marie Paquet-Deyris, « Alan Ball's California and Louisiana Series, Six Feet Under \& True Blood: a Troubled State of the Nation », TV/Series [Online], 1 | 2012, Online since 15 May 2012, connection on 05 May 2019. URL : http://journals.openedition.org/tvseries/1195 ; DOI : 10.4000/tvseries. 1195

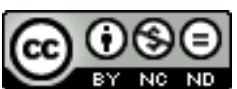

TV/Series est mis à disposition selon les termes de la licence Creative Commons Attribution - Pas d'Utilisation Commerciale - Pas de Modification 4.0 International. 


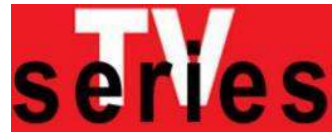

\author{
Alan Ball's California and Louisiana series, \\ Six Feet Under \& True Blood: \\ a troubled state of the nation \\ Anne-Marie PAQUET-DEYRIS
}

\begin{abstract}
Alan Ball, the critically-acclaimed screenwriter of American Beauty, launched his first series project in 2001 with Six Feet Under. His somber but humorous account of the dysfunctional Fisher family's life and death in suburban Los Angeles held a fascinating mirror to contemporary American culture, ideology and alternative lifestyles. Talking to the Dead, while providing a direct access to the characters' inner consciousness, allowed the characters to broach all kinds of taboo motifs and notions. When Ball's latest series True Blood came out on HBO in 2008, the same sense of broken taboos and overstepped limits held the spectator captive. This time, the Dead were talking and fighting back to integrate into human society. Adapted from Charlaine Harris' "Southern Vampire" collection of books, Ball's protagonists even as vampires struggling for the Vampire Rights Amendment were only too human, riddled with coming-of-age worries and plain Angst. How then does Alan Ball inscribe the evils of simply living in contemporary America? Which subtle and not so subtle games of echoes unfold between the two widely successful and creative shows?
\end{abstract}

\begin{abstract}
Al kinds of taboo notions can be tackled when the Dead talk. Academy Award-winning screenwriter Alan Ball did find rather unconventional channels to allow the characters of his television series, Six Feet Under and True Blood, to voice their sometimes taboobusting opinions. These strange voices seem to say it all and combine with an equally daring imagery leaving a long-lasting visual impact. Whether with the visiting Dead from the five seasons of Six Feet Under (2001-05) or with the Dead until Dark straight from Charlaine Harris's adapted Southern Vampire Mysteries in True Blood (2008-the present), Ball strikingly inscribes the evils of simply existing in contemporary America. Providing a direct access to the characters' inner consciousness in his first series and staging a mind-reading heroine in the second create a specific filmic grammar few directors have ever used before. His visual signature involves a form of hybrid TV/film, even painterly, language departing from more conventional television formulas.

As he toys with the high reactivity of American series in a surprisingly refreshing manner, Ball explores social, societal and political issues to create an immediate bond with the spectators. We are held captive by his staging of constantly overstepped limits and dysfunctional families in the two widely successful and creative shows. The deep fascination they hold is strangely amplified by their dark and
\end{abstract}


pervasive humor. How then does Alan Ball articulate a discourse on the ailments of the nation? Which representational strategies and generic conventions does he use to represent American culture, ideology and alternative lifestyles in a "realistic" show and a supernatural/horror one? Which kind of echoes of the survival of the troubled heroes in a chaotic world is there between the two series?

\section{"A journey to the center of the mind" (a song by The Amboy Dukes)}

When Ball launched his first series project in 2001 with Six Feet Under, his American Beauty screenplay had just met with wide critical and public acclaim. His somber but humorous account of the life and death of the dysfunctional Fisher family in suburban Los Angeles held a complex mirror to contemporary America. And so did in 2008 the odd members of Bon Temps reconstituted family in True Blood. Even though they evolve in a deliberately fantasized universe, Ball had Harris's "Southern Vampire[s]" fight for the Vampire Rights Amendment to integrate into human society and display human, coming-of-age worries. To varying degrees, both opuses inscribe on screen alternate realities while recycling various generic conventions from comedy to melodrama, horror and even soap opera.

In a June 6, 2002 issue of Variety, Daniel Frankel called Six Feet Under "this metaphysical soap opera whose theme is death" (A1), but the earlier series as much as the more recent one are really stories about characters whose biggest enemies are either specifically identified forces in society (religious fanatics or gay-bashing and homophobic groups and serial killers disguised as law-abiding citizens) or quite simply themselves (David eventually deciding to make his coming out in Six Feet Under). So that the first show centered around a death-care facility and the second one focusing on the violent relations between humans and vampires in some imaginary Southern small town both map out the face of America with their individual and communal stories offering no easy answers.

Both series' first season DVDs feature two similar close-ups of women's red lips against cadaver-white faces. 

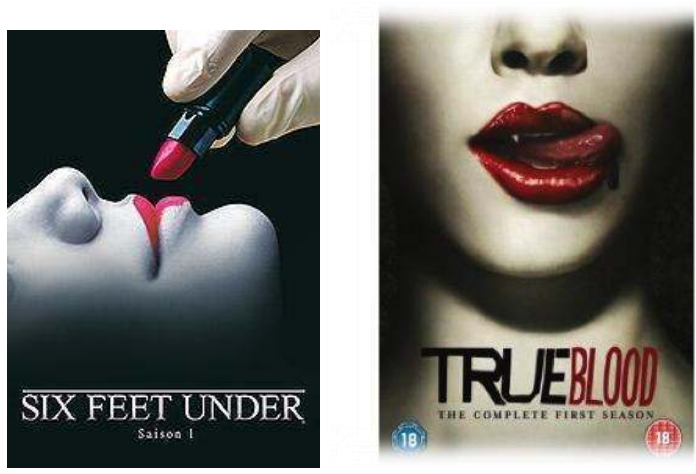

Six Feet Under and True Blood First Season DVD jackets

\section{An idiosyncratic aesthetic}

The iconography, at once enigmatic and highly recognizable, already captures the utter singularity and bizarre idiosyncrasy of Ball's mental universe. The first woman's lips are being made up by a mortician whose white-gloved hand is only partly visible in the frame while the second one's red tongue sticks out to lick a drop of blood, a white fang showing. The ironic play of visual echoes between the Dead and the Undead is emblematic of Ball's major interest in the living's relation to death and desire. It operates as a promise of dysfunction and some kind of disturbing "Journey to the Centre of the Mind", to quote the title of Nathaniel Fisher's favorite song his son Nate plays after his death in the sixth episode "The Room". It also highlights the extent to which Sookie Stackhouse's universe actually mirrors the (slightly) more reality-grounded world of the Fishers in their California funeral home. But what is so specific about the treatment of genre and gender at the heart of Alan Ball's remodeling of television series rules?

Director of photography Alan Caso developed with Ball what the latter calls "an anti-TV language". Caso describes Six Feet Under's «frigid » imagery as:

[...] a combination of very painterly, motivated, natural lighting, desaturated colors and lots of depth. [...and l]et's not be afraid of the wide shot - let's go really wide. Let's provide these proscenia for the actors to play in and make bold statements about the emptiness of someone's life by isolating him, creating a conflict within the composition of the frame, or show his misery by making him look small and insignificant in the frame. ${ }^{1}$

${ }^{1}$ Quoted by Ron Magid in "Family Plots", American Cinematographer v. 83 n 11 Nov. 2002, p. 71-73, [p. 70-72; 74-79]. 
This unique visual language offers a keen insight into the characters' streams of consciousness sometimes actualized on screen by the sudden inscription in the frame of the deceased's ghosts. Using a natural device to translate some unnatural phenomenon seems to be one of Alan Ball's favorite tricks. Whenever the Dead resurface on screen, the ongoing dialogue with the living protagonists eerily functions on two levels. It looks as if an actual exchange were taking place with the character at times directly addressing the ghost. But whenever another protagonist enters the ghost simply disappears and the dialogue awkwardly goes on for a while after the he has departed. These sketches' mood and visual style stand apart as such muted, slowpaced scenes materialize the characters' sense of profound disconnection, of being frozen in time in a very organic, literally visceral way. Ball first uses the process on screen in Episode 1, a pilot he both wrote and directed. He was careful to announce this ghost sequence by first inserting a flashback straight out of the older brother's mind (Peter Krause). He playfully reinvests the conventions of the horror movie immediately before filming Nate's reminiscence of his first childhood encounter with dead bodies. After a fade-in on David (Michael C. Hall) standing by his dead father at the morgue, Ball first inserts a darkly humorous ad on Living Splendor embalming fluid before a fade-out and a slow descent to the dimly-lit embalming room downstairs [23:38-25:41] $]^{2}$. The eye of the camera is the only focalizer here, somehow standing in for some hypothetical killer or personification of Death stealthily going down the steps. This strange and brief fusion of thriller and horror is enhanced by the cross-cutting between the unassigned viewpoint and the close-ups and extreme close-ups of some unidentified mortician working behind the room's thick glass and manipulating various scalpels and tubes. But the sequence eventually leads to a slightly low-angle series of brightly lit and greenish shots of Fisher Sr. The children's viewpoints are of course emphasized here as both Nate and his little brother David take in the nature of his work. The actual ghost scene only occurs a few scenes later when David prepares his father's body in the basement. Nathaniel Fisher (Richard Jenkins) suddenly reappears in the frame and starts talking [33:25-34:40], literally embodying his son's inner voice and the stern critical comments the latter imagines his father would have made. When Federico (Freddy Rodriguez), the Fishers' gifted embalmer, walks in, David is still talking back to the corpse but his father has by then vanished off screen and the three-shot turned into a two-shot. Alan Caso positions his camera as close to David possible, literally invading his private space so as to underscore his discomfort. The impact on the viewer is direct, making the protagonist's unease

$2<$ http://www.megavideo.com/?v=L11CNVCY>, last viewed on 13 November 2011. 
somehow ours. Caso insists that this consists in a deliberate strategy of destabilization:

Viewers are not just armchair observers of this world; we're putting them right in the middle of it, forcing them to feel the discomfiture of David and the other characters. There's no backing away, there's no getting out of it. (Magid, 74)

This style of photographic treatment is emblematic of David's character. But Ball and Caso also use different types of treatment for the other characters' idiosyncrasies. They mostly film Ruth Fisher for instance, the distant mother (Frances Conroy), sitting apart from everyone else or Nate frozen in thought and reminiscing scenes from his past and childhood, often channeling the others' pain. Technically, the usual brightness if not overexposure of these sequences frames the character and provides the viewer with valuable insights into his inner world. The style of composition is key to understanding him and his mostly skewed relation to the outside world. It also often replaces the traditional close-up. In this sense, the "ghosts" are really literary devices to articulate the protagonist's stream of consciousness and inscribe on screen just another type of reality functioning in parallel with other reality levels. This variety of visual schemes also applies to locations. The kitchen seems to be the safe center and nourishing place in the Fishers' lives. It contrasts with the other part of the house, the funeral home. Ball and Caso often capture the family members actually connecting with each other in this relatively cosy hearth which functions like the visual antithesis of the clinical-like transition chamber and its threateningly intimate insights into the world of death. These two places in their very contiguity materialize what Alan Ball is most interested in, a space where life and death intersect and interact and at times coincide.

Dark humor tempers the dreary dimension of these constant brush-ups with death and provides another way of playing with narrative and formal expectations. The fact that the generic conventions of horror are not being fully recycled and combine with family saga, soap opera, pathos, melodrama, romance or even farce and elements of the grotesque heralds True Blood's ironic representation of the Undead and its hybrid creatures. Somehow hybridity, and generic hybridity in particular, becomes the sign of the shows' dexterity and the very condition of their pleasurably incisive power.

\section{What Lies Beneath}

As critic Sally Munt underlines: 
Typical HBO products are aimed at adult entertainment audiences on cable and satellite television. These individual units are coded as writerly texts, programmes that require competent readers versed in a range of genres and institutional forms. [...]

HBO, although owned by global conglomerate Time Warner, sells direct to customers by subscription, thus the HBO stable's "Unique Selling Product," or appeal, is creative, quality TV with a critical edge, an elite brand in a mass market industry. ${ }^{3}$

And creative freedom is exactly what Alan Ball seems to be having in both series when tackling the delicate topic of the American Family in the industrial context of network television. The point is precisely to walk away from some "networky" and clichéd treatment. Embarrassing truths were really what the two groups of writers working on the shows were willing to expose. In True Blood more specifically, this sense of exposing what lies underneath sometimes thinly-veiled surfaces takes center stage. Exposure is enacted precisely by staging the palpable sense of place in the Louisiana series and, to a lesser extent, in the California one as well. Georgia-native Ball uses the aesthetics of place the way Southerners Eudora Welty and Flannery O'Connor did in their essays and stories. O'Connor is actually the most vocal in highlighting the relationship between "the country, with its body of manners", the "Southern school" and "the image of Gothic monstrosities and the idea of a preoccupation with everything deformed and grotesque" it conjures up (O'Connor, 28). The sense of belonging to a specific region but also to one big extended family, of being impacted by it as much as by "the racial nightmare" (Baldwin, The Fire Next Time) and by class, gender and species issues stems from the peculiar status of the southern soil and "manners". Ball's latest series could qualify as a contemporary "Southern" within the framework of the supernatural genre, which oddly coincides with O'Connor's defining much of her fiction as "tak[ing] its character from a reasonable use of the unreasonable [so that b]elief [...] is the engine that makes perception operate" (O'Connor, 109). With Ball, the mechanism of suspension of disbelief doesn't only procure a semblance of truth but the semblance of a multitude of truths. The analysis of racial difference Ball and his writers had started working on in his first show is taken even further in True Blood although often in a humoristic way. Sookie's best friend, Tara, highlighting for instance how ironic it is for an African American girl to be called Tara after Southern Belle Scarlett O'Hara's quintessential plantation home in Gone With the Wind. Even though a strong woman, Tara is often pictured cornered into difficult situations as when kidnapped by a vampire who paradoxically treats her as a princess and a

3 Sally Munt, "A Queer Undertaking. Anxiety and reparation in the HBO television drama series Six Feet Under", Feminist Media Studies, Vol. 6, Nº. 3, 2006, p. 263-64, [p. 263-80]. 
captive/sexual slave. The shock of violence inherited from the South's Peculiar Institution is here displaced onto this untenable condition and provokes audiences into rethinking their own at times thinly-disguised prejudice. Popular culture becomes an ideal medium for a ritualistic treatment of America's troubled history. As Franklin the Master Vampire starts taking Tara's life over, he is staged as the bad object of popular culture in which Otherness is rooted and "whose mythologies must be seen, announced, and renounced in a powerfully ritualistic motion 4 ". The way in which Tara reacts to her violent experience shows her as both vulnerable and with a strong will to survive, and runs counter to the dominant discourse of "media violence affect[ing] social behavior, always with a distinct ideological agenda hiding behind the façade of empirical observation, statistics, and 'objectivity'5".

\section{True Blood's ground-breaking title sequence}

Digital Kitchen's title sequence offers some sort of kineticised stylization of actual and fantasized images of the Deep South in a singular visual patchwork. Southern Gothic finds here a literal incarnation. Instead of focusing on shots that would resurface in the show, Digital Kitchen executive director Mark Bashore explains that the team members started touring Louisiana looking for people, places and things that caught their eye. Their incentive was rather to create a visual prologue from scratch with a mixture of Super $8 \mathrm{~mm}, 16 \mathrm{~mm}$ and high-definition video rather than announce and underscore some of the sequences to come. In an eerily naturalistic manner, they capture Nature as a predator and inscribe the brutal impact of the Southern environment on individuals ${ }^{6}$.

\footnotetext{
4 Matt Hills, when reviewing Christopher Sharrett and Grant, Keith's Mythologies of Violence in Postmodern Media, Wayne State U. P., Detroit, 1999, p. 9.

5 Christopher Sharrett and Grant Keith, op. cit., ibid.

${ }^{6}<\mathrm{http}$ ://www.youtube.com/watch?v=rot-cyyDYZs >, last viewed on 13 November 2011
} 


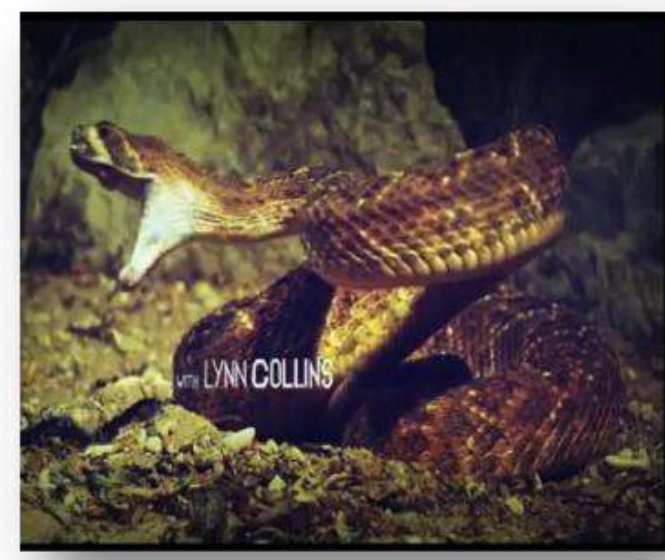

Shot of predator in True Blood's title sequence, Season 1, Episode 1 and following

Representation of predation extends from roadkill and a carnivorous plant closing down on a frog to sex scenes and a lusciously-red open mouth sucking in white smoke. The quick juxtaposition of profane and religious takes generates unvarnished, crude views of the area and its people. Transitions between shots enact this sense of some unrelenting pressure of the outside world on the protagonists. The last frame of one shot and the first frame of the next are blown up and made to overlap "to achieve the effect of one image cracking, boiling and shriveling into another" says creative director Matt Mulder. He explains that:

Our motivation was [the idea of] sloughing skin, almost like a rattlesnake molting. In his conversations with us, Alan referred a lot to the supernatural - not only vampires, but shapeshifters and other [mythical] wilderness creatures - so we wanted to suggest a transformative animal state. 7

Because the entire title sequence is shot from a predatory viewpoint, a sense of threat and potential transformation precisely seeps from this unidentified beast-like entity which seems to regard everyone around as potential prey. As the camera frames some slimy catfish in the murky waters of a Louisiana bayou, it also creates the

7 Iain, Stasukevich, "Short Takes. True Blood Titles Set Southern-Gothic Tone", American Cinematographer v. 89 n 12 Dec. 2008, p. 14, [p. 10-14]. 
creature's viewpoint. As the beast draws closer to civilization and humans, its first point of view shots suggest blood-lust the way Jeff Fazio's own title sequence in his television horror anthology series The Hunger $\mathrm{did}^{8}$. In the DVD extra's audio commentary of the pilot episode he also wrote and directed, Ball specifies:

I wanted this show to be a lot more cluttered and a lot more messy than Six Feet Under because it's completely different and the show is not about the control of emotions that might feel dangerous. If anything, the show is about total lack of control all the time or, no control all the time.

Absence of control is exactly what the creature's roving point of view seems to achieve as it conditions the spectators to expect the conventional blood spatter of vampire movies. Jace Everett's "Bad Things" country song ("Before the night is through, I wanna do bad things with you", 2009) somehow compounds this sense of dread already suggested by the strange mix of the sacred and the trivial. Artful frame compositions alternate with scenes simply meant to capture fast motion as when giant lit-up crosses gleaming in the dark southern night suddenly interchange with more trivial scenes like GoGo dancers performing highly sexualized dances. All express in some radically different ways what the series creator calls "the human need to [...] have some sort of transcendent experience". And the difference may precisely lie in the fact that these views of sexuality and mortality are not so much essentially subversive as formally - and literally iconoclastic. They contradict the established grammar of current title sequences usually unfolding as a visual echo/summary of the main plotline. Ball's variations operate from the start as generically-blended, highly stylized tales whose unsettling symbolic power is enhanced by the Gothic setting in Six Feet Under.

In the latter, the title sequence's comprehensive collection of images perfectly reflects its source material. The blunt and cursory way of superimposing the actors and Alan Ball's names on death-related images inscribes constraint, repression and plain disappearance on screen, as does the show's name framed in a rectangle shaped like an underground grave ${ }^{9}$.

\footnotetext{
8 This fascinating title sequence is available at: http://www.youtube.com/watch?v=tCDHq2roE4I, [0:00-0:59], last viewed on 20/02/2012.

9 http://www.youtube.com/watch?v=KYAeoqwg9Yw, last viewed on 13 November 2011.
} 


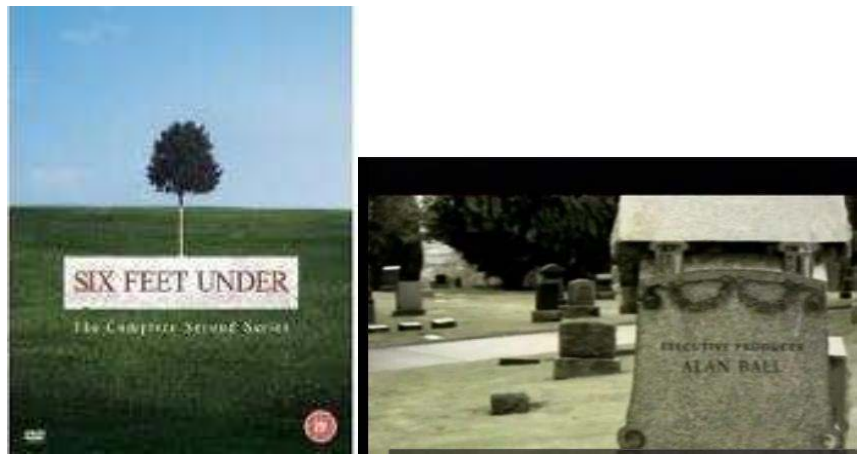

DVD jacket of Six Feet Under's second season and Ball's name on a tombstone in the title sequence of the series

In the second show, emotions are let loose and start prowling around like full-fledged murderous entities. The same mechanisms of attraction and repulsion are at play and the protagonists' psychological disarray is mirrored by the narrative meanders and mosaic of various reality levels. When Sookie Stackhouse has erotic dreams about Eric rather than her vampire lover Bill Compton for instance, the status of these images as either fantasies or actual prolepses remains unclear and this parallel dimension somehow contaminates the main storyline. The serial medium and its repetition principle of course heightens the power of fascination exerted by these real and phantasmagorical processions of seminal images constantly hovering between sensuality and brutality, rapture and morbidity. The sets of the two series consistently serve as paradoxical backdrops for the labyrinthine stories of characters always standing on some opaque threshold at the frontier of hidden stories. In True Blood's opening titles, the silhouettes of Ku Klux Klan members partially shot in the frame behind a startled youngster looking straight at the camera materialize this constant play on exhibition and concealment, primal emotions and feelings running deep but ready to erupt. 


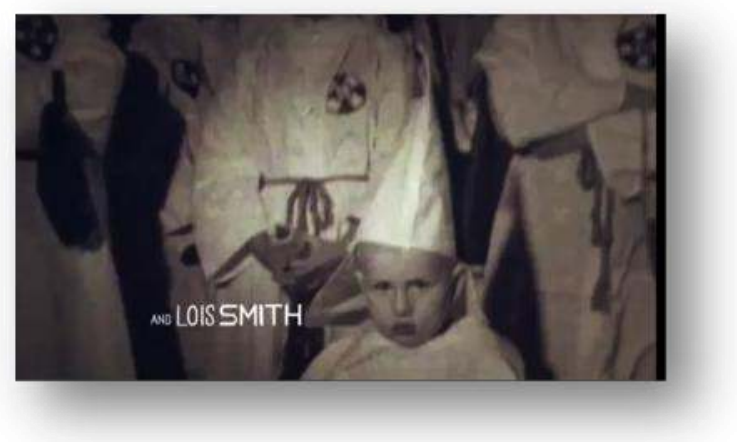

True Blood's title sequence with shots of Ku Klux Klan members and a child in full regalia

True Blood however is first and foremost a drama about the interaction between humans, vampires and supernatural others in a Louisiana community, both inside and outside of the small-town confines of Bon Temps. The numerous references to Civil Rights, Vampires Rights, race, drugs and sexuality issues seem to function mainly as quick but often surprisingly humorous and insightful forays into America's organized religion as well as social and political history. But the mechanisms used by Ball differ to some extent from what theoretician Pierre Macherey used to call "ideological projects" in 1966. The multiplicity of narratives and subplots series are made of usually allows for a variety of interpretations which mostly escape their creators' intents and the TV spectator's conscious reception. But for Ball, the whole point is precisely for these interpretations to proliferate and reconfigure in the cracks and fissures of the series he also conceives as a shared cultural artifact. Hence for instance his conception of spare dialogue: "We'll always choose subtext over something overt. Nothing is on the nose. The best writing is when you understand why someone's doing something without having it explained" (Rabinowitz, 42-43). Hence also his frequent use of the suggestive dimension of the fantastic deliberately leaving the spectator some leeway to interpret a character's expression or action. Sam Merlotte's strange looks and stealthy attitude (Sam Trammell) for instance in the first season as Sookie's friends are being murdered is already a way of suggesting his only partly-human essence, while half playing with the possibility that he may be the killer. The point here seems to be that some characters are not readable at first sight and that the spectators have to read some meaning into them. This hidden sense will of course depends on their own hermeneutic approach and will inevitably run counter to the diverse reactions of other spectators 
worldwide. Thus the characters' positioning remains challengingly open to interpretation just as the particular issues attached to them. Of course, the very structure of the serial medium organizes the narrative in various layers of truth and subtexts. But Ball choreographs these according to uncanny patterns unfolding in familiar contexts so that whatever reemerges does so with distinctive stylistic, narrative and aesthetic effects. Sam for instance looks like a prototypical "regular guy". The camera however consistently frames him in close-up with a mysterious look on his face inscribing his dark secret on screen and somehow triggering the spectator's detection compulsion.

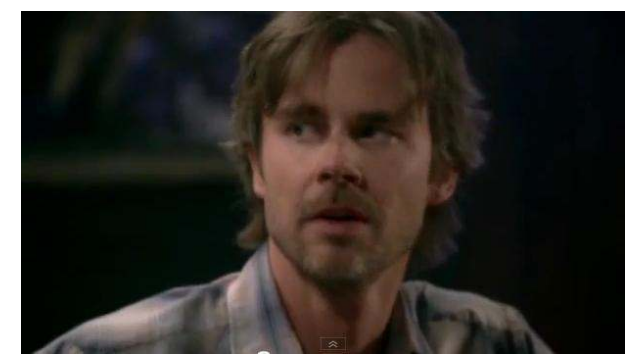

True Blood's Sam Trammell, owner of Merlotte's Bar and Grill, often framed in close up throughout the series

In a highly metafilmic manner, the two elaborate, highly stylized title sequences already demonstrate that interpreting images involves hard work but also intensely pleasurable surprises for the spectator.

\section{Staging deadly crises}

As French critic Martin Winckler underlines, Six Feet Under is mostly a fantasmatic series buzzing with the most conflicting voices and visions. True Blood however brings the sense of the macabre to extremes within the confines of a strangely familiar even though fantastic series. In both cases, the constant interaction between the same groups of actors and the serial format imposes rather violent modes of confrontation and literally provokes the spectator's decoding game. Whatever the generic framework, Ball and his co-writers mostly rely on the emotional realism of their characters to rivet the spectator's attention. Because each episode of Six Feet Under begins with a death, it provides a thematic structure and launches a fictional exploration of death and its surrounding rituals. But the focal point remains the actual body and the way in which it is grounded in a particular history. The final reality becomes the starting point of yet other fictional 
explorations which intertwine with the Fisher family's already complex story. The combination constantly recycles what Ball repeatedly calls "the human element", which accounts for both series flirting with the dynamic of soap opera (Keith and David's tortured homosexual love story for instance) and the type of human emotions and thrills melodrama engages (Sam Merlotte-Sam Trammell's unrequited love for Sookie). Even though the comic dimension is an essential component of Ball and his collaborators' script-writing technique, resurgences of the tragic can contaminate the diegesis in a highly emotional way. If Alan Ball's series profoundly differ from the other TV products because of the intensity of their representational modes of the terror of loss and dissolution. Whether literally or metaphorically, inscribing on screen "the terrors of intimacy" means chronicling the devastating crises that stem from it. Here's how Ball comments on the narrative mechanism of True Blood:

Overall the show is about the terrors of intimacy, in that when you really, really open up and let another person into your life and psyche, it can be terrifying - especially when that person is a vampire. ${ }^{10}$

In episode 9 of season 2, Ball and his screenwriters draw on the romantic vampire figure in a distant homage to Coppola's Dracula and have vampire sheriff Eric Northman (Alexander Skarsgard) shed tears of blood when his maker Godric decides to take his own life [45:4551:10 $]^{11}$. In such a scene, the temptation of melodrama (a vampire plans his own death with a human-like logic) truly combines with romance and the sensational to federate the largest viewership possible. The strong bond between Eric and his father-brother-lover comes to a dramatic end as the two-thousand-year-old vampire literally burns bright in the rising sun in a spectacular superimposition of close shots of his upper body and face and the sun's halo-like incandescent light

${ }^{10}$ Sarah Lucy May and Jenny,Eden, "Bad Times in Bon Temps", Deathray n 21, Oct. 2009, p. 50-51, [p. 48-55].

${ }_{11}<\mathrm{http}: / /$ www.youtube.com/watch?v=m8rvW3C-qEA >, last viewed on 13 November 2011. 


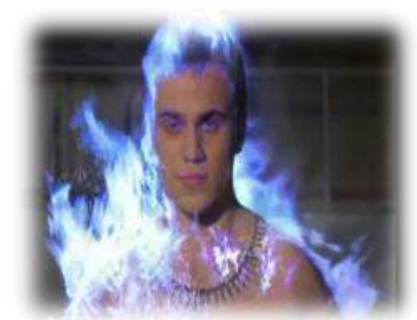

Vampire Godric committing suicide in True Blood's Season 2, Episode 9

There might not be any overall glamorized treatment of the characters (so far in the on-going series, Godric is the only vampire to display a truly human bordering-on-the-godlike sacrificial dimension), but director Scott Winant's constant use of close-up shots stimulates the spectator's desire for connectedness by having Sookie cry in the background while watching Godric's body being consumed. Each episode dramatizes in its own idiosyncratic way this acute crisis of desire and fear of intimacy and death. To a certain extent, staging the fears of affects in so many raw and unprecedented ways deflects the issues of the fears and catharsis of the audience. Emotional and societal problems take center stage even in the generic context of horror. The same pattern is at work when Jason Stackhouse gets involved with the Fellowship of the Sun's Reverend Steve Newlin in Season 3, Episodes 9 and 10. Jason is dangerously attracted to his reactionary ideology "For a Safer, Sanctified World" free of vampires and other unwanted. His trials and tribulations somehow reflect the current pull of religious fanaticism, sectarianism and the debate on the fundamental right of self-defense inscribed in the Second Amendment to the United States Constitution. As a soldier and potential crusader of Steve and Sarah Newlin's church, he comes to believe in the legitimacy of organized violence within the defined territorial boundaries of the temple and eventually outside. The intensity of his own personal crisis born of his resentment for his sister's vampire lover is so realistic that only some outside intervention and his ties to caring relatives can actually tear him away from such a self-sufficient and paranoid environment. And the outcome is indeed bloody, if not for Jason himself, at least for quite a few of the sect's members and enemies. This individual story of violence and sex (Stackhouse's adulterous relationship with Mrs Newlin is both ironical and a sign of how lost he feels) is emblematic of a face of America which has been prominent in the American media for the past fifteen years. 


\section{similarities \\ film, Towelhead: formal and thematic}

In 2007, Ball directed Towelhead, a controversial film telling another unvarnished story of a teenager discovering adult sexuality. In a more truly subversive way, the movie capitalizes on the violence of the disclosure orchestrated as a blow to the spectator. The entire filmic diegesis hinges round the notions of crisis and direct confrontation. But the treatment remains unchanged in the sense that once again, Ball tells a profoundly human story without taboos, managing to circumvent the twin polarities of good and evil. As in Six Feet Under and True Blood, the monster is not fundamentally "other". Actor Aaron Eckart plays the rapist and racist pedophile Travis Vuoso and repeatedly asserts, "I'm not a bad man", bringing to our cultural consciousness in a very unsophisticated manner what film scholar Janet Staiger calls "certain sexual energies [which] are repressed such as bisexuality, homosexuality, and child sexuality ${ }^{12}$ " And because these repressions are actually displayed, simply mises en scène, we can work through them developing our own affective trajectories and cognitive thinking. The "aesthetics of distance ${ }^{13}$ " usually suppressed in sexuallyexplicit material is also reinstated in a film dealing so frontally with sexual desire and behavior. But the focus of the young girl's story is rather the mechanics of desire than control and the violence and aggression which correlate with it. She is framed as defying dominant sexual values, an abiding feature of most female characters in Ball's series where all females eventually assert their own right to sexuality.

\section{Staging the end}

In the concluding sequence ( $\mathrm{S}_{5}$ : E63) of Six Feet Under he wrote and directed, Alan Ball has young Claire Fisher driving off East [1:00:10-1:05:01]. The sequence is filled with hope and nothing seems to be able to stop its powerful surge forward but the actual inscription of each central character's death. Technically, with Ball putting an end to the protagonists' strange and miraculous intimacies with death and having them confront the ultimate trauma, the filmic diegesis has to come to a halt. The composite visual structure and treatment of the final four minutes of episode 63 very much resemble one of Claire's photo collages - montages actually. As she's taking one last picture of her family in front of the funeral home, Nate's ghost whispers into her ear, "You can't take a picture of this. It's already gone". And indeed, the parallel editing of short takes of the characters' futures and deaths and

\footnotetext{
${ }^{12}$ Staiger, Janet, Media Reception Studies, New York and London, New York UP, 2005, p. 174.

${ }^{13}$ Op. cit., 185.
} 
of Claire's progression blurs the distinction between the flash-forward and the mental projection/visual recreation. In some rapid succession of shots mediated by her (camera) eye, she seems to be literally editing out her relatives and friends' lives, dramatically piecing together the seminal moments of their lives and deaths. These images seem to be emanating straight from the most intimate part of her experience as a photographer just like the framed pictures on her wall [1:04:551:05:15]. The striking close-up of her as an old dying woman in New York with wide open cataract-covered eyes [1:05:17] is quickly replaced by a close shot of younger Claire's searching and literally visionary eyes [1:05:25] still driving off into the Mojave desert light ${ }^{14}$. The effect is very similar to Kuleshov's montage-of-attraction and creative geography ${ }^{15}$. All linked together through the fast-paced montage, these visions seem to materialize on screen all the protagonists' fantasized geographic and emotional realities. Their visual and contextual similarities aptly epitomize the entire show's motto adorning the $5^{\text {th }}$ season DVD jacket like a definitive haiku guiding one last time the viewer's associations and thoughts about his own mortality:

\section{Everything. \\ Everyone.}

Everywhere.

Ends.

One single word on each line and a period inscribe absolute finality in a simple, irreversible way, just as the camera's final tilt-up from the road to a white sky and screen summons up the end of these " ensemble stories » (Ball quoted by Parker, 25) and human crises TV lends itself to so well [1:05:49-1:05:58].

\footnotetext{
14 <http://www.youtube.com/watch?v=el4eUKmLujg>, viewed on 13 November 2011 15 In the 1910 and 1920 , Russian director Lev Kuleshov's experiments revealed how separate shots simply following each other could suggest emotional and geographic connections which do not exist
} 


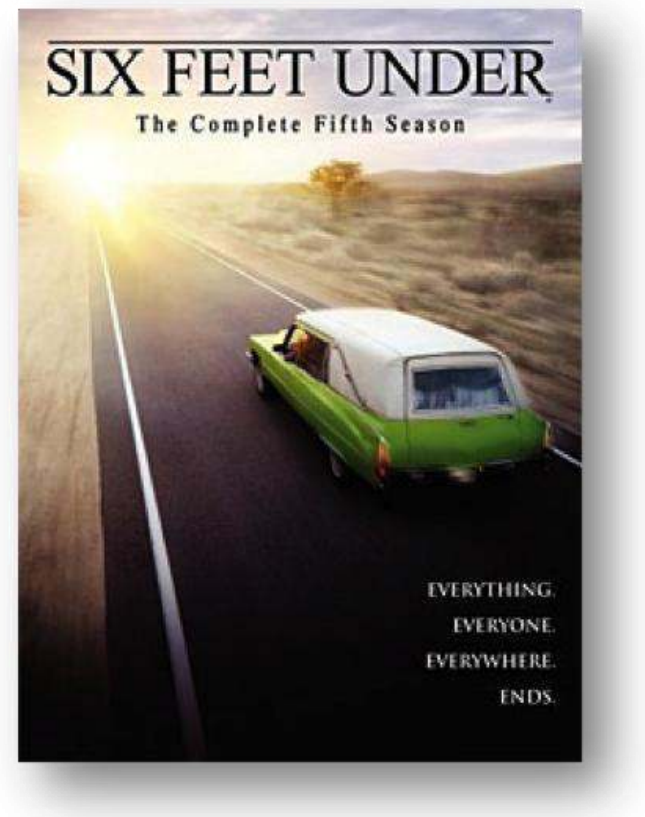

DVD jacket of Six Feet Under's fifth and last season: Claire Fisher driving across the continent from Los Angeles to New York

In this strangely condensed road movie-like sequence, the staging of some inescapable destiny also harks back to Kubrick's iconic aerial shots of the small car of the Torrance family making its way up to the fated Overlook hotel in Shining.

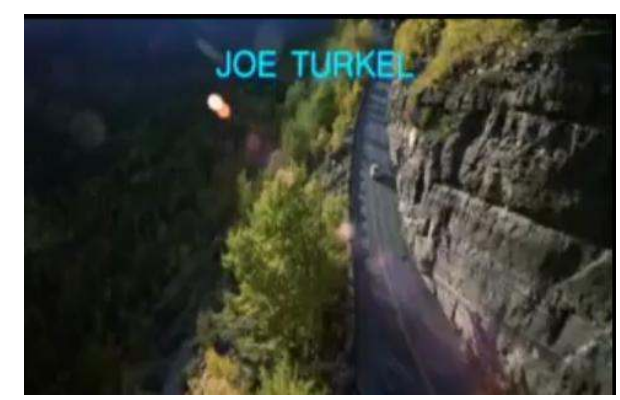

Title sequence of Stanley Kubrick's Shining: the Torrance family driving up to the Overlook hotel 
But this special effects ending has little to do with the ruminations about self-obsession that will destroy Jack Torrance and seems more geared at transcending them through a clear metafilmic allusion to the photographer-director's work, seizing our attention so that we in turn can practice some constructive editing. Somehow this final sequence also harks back to the more disturbing depiction of an economically static society. The Fisher sons are compelled to become undertakers just like their father and they come close to being taken over by the evil Kroehner mortuary conglomerate in the first two seasons, getting away with it only through arson. As Robert Tobin underlines, "A real caste system seems to obtain in Ball's world. [...] The lack of any suggestion of possibilities for progressive social change is perhaps realistic, but ultimately more of a downer than the series' meditations on death" (Tobin, 88). Freedom in Six Feet Under is relative and seldom of an economic nature. Somehow the characters' emotional limitations seem to be echoed by the fight to the death that making it and barely surviving in a city like Los Angeles entail.

\section{Strange fascination: serial time, serial actors}

Martin Winckler stresses the strange fascination of critics from the French intelligentsia for Six Feet Under (Winckler, 139). Part of the answer may simply be that not despite but because of Ball's eerie mixture of the tragic and the comic, the hermeneutic mechanisms he provides the viewer with in both series address in a novel way some of the fundamental issues film also explores. But it may also very well have to do with the kind of ironic distance he puts into most of his fiction. As Richard Dyer underlines in his 1986 classic book Heavenly Bodies. Film Stars and Society, these are issues "the growth of feminist and gay politics [...] have put directly on to the political agenda [such as] questions of emotions, sexuality, everyday life and more generally what being a person is and can be" (Dyer, x). And more specifically, they tackle on a regular basis and in an extremely concentrated, direct and often unadorned mode the fundamentally political issue of representation Dyer sums up in the following way:

[...] how do we understand how a given group of people are placed by the media? What are the possibilities of political intervention in the media? How can people as audiences use the media? How important are subcultures? ${ }^{16}$

Most of the actors Alan Ball chose brought interesting interfilmic echoes and already-structured well-known personas to the shooting of the two series whether it be Frances Conroy, one of playwright Arthur

\footnotetext{
${ }^{16}$ Richard Dyer, Heavenly Bodies. Film Stars and Society, London, BFI, 1986, p. X.
} 
Miller's favorite actresses, Michael C. Hall who also plays in the Showtime and CBS show, Dexter, or Anna Paquin who won her first Oscar at age eleven starring in Jane Campion's 1993 The Piano. Their high-quality performances shape the (quasi-)reverential way in which most spectators and of course fans see them, so that when this type of television-formatted fictionalization deliberately crosses various symbolic boundaries, the audience is ready to take them all in, willingly lending itself to Ball and his contributors' sometimes irreverent play with film language, intertextual echoes and brilliantly allegorical, though profoundly unsettling and pleasurably thought-provoking strategies. 


\section{Bibliography}

Aoun, Steven, "In the Ghetto: a Year in Review (2002)", Metro Magazine $\mathrm{N}^{\circ}$ 135, 2003, pp. 196-201.

Ball, Alan, Six Feet Under, DVD, HBO [2001-05]

True Blood, DVD, HBO [2008-?]

Towelhead, DVD, 2007 [Aaron Eckhart, Toni Colette, Maria Bello, Peter Macdissi, Summer Bishil]

Bernstein, Abbie, "Let the True Blood Flow", Fangoria n. 276, Sept. 2008, pp. 26-29; 82.

Buxton, David, Les séries télévises. Forme, idéologie et mode de production, Paris, L'Harmattan, 2010.

Dyer, Richard, Heavenly Bodies. Film Stars and Society, London, BFI, 1986.

Kinder, Marcia, "Review of Scenes from a Marriage, by Ingmar Bergman”, Film Quarterly 28, no. 2 (1974-75), pp. 48-53.

Littwin, Susan, "Not Rated", WGAw Written By V. 6 n. 3, March 2002, pp. $40-47$.

Magid, Ron, "Family Plots", American Cinematographer v. 83 n 11 Nov. 2002, pp. 70-72; 74-79.

May, Sarah Lucy and Eden, Jenny, "Bad Times in Bon Temps", Deathray n 21, Oct. 2009, pp. 48-55.

Modleski, Tania, Loving with a vengeance. Mass-produced fantasies for women, New York, London, Routledge, 1990.

Munt, Sally, "A Queer Undertaking. Anxiety and reparation in the HBO television drama series Six Feet Under", Feminist Media Studies, Vol. $6, \mathrm{~N}^{\circ} .3,2006$, pp. 263-80.

O'Connor, Flannery, Mystery and Manners, New York, Farrar, Straus \& Giroux, 1991.

Parker, Robin, "Red-blooded TV with a bite”, Broadcast 10 July 2009, p. 25 .

Sharrett, Christopher and Grant, Keith, Mythologies of Violence in Postmodern Media, Wayne State U. P., Detroit, 1999. 
Staiger, Janet, Media Reception Studies, New York and London, New York UP, 2005.

Stasukevich, Iain, "Short Takes. True Blood Titles Set Southern-Gothic Tone”, American Cinematographer v. 89 n 12 Dec. 2008, pp. 10-14.

Tobin, Robert, "Six Feet Under and Post-Patriarchal Society", Film \& History, Vol. 32.1 (2002), 87-88.

Winckler, Martin, Les Miroirs obscurs. Grandes séries américaines d'aujourd'hui, Au Diable Vauvert, Vauvert, 2005. 